\title{
Repercussions of child cancer in the daily life of a family caregiver
}

\author{
Repercussões do câncer infantil no cotidiano do familiar cuidador
}

Repercusiones del cáncer infantil en el cotidiano del familiar cuidador

Eduarda Gayoso Meira Suassuna de Medeiros $^{1}$, Rosana Farias Batista Leite ${ }^{1}$, Déborah Karollyne Ribeiro Ramos ${ }^{1}$, Layze Amanda Leal Almeida ${ }^{2}$

It aims at investigating the effects of cancer diagnosis in the everyday life of families whose children have neoplasm. This is a qualitative study with exploratory-descriptive focus, with semi-structured interview as a tool for gathering information. The research was conducted at the University Hospital and the Institute of Paraiba Against Cancer, both located in Campina Grande/Paraíba, Brazil, between July and September 2012. The empirical material was analyzed following proposed content analysis. Results showed that the quality of social life, psychological symptoms and personal growth were affected. We concluded that caring for a relative with neoplasm, especially if this is a child, it is a challenge for the family. However, it is possible to build good experiences living with the sick child and face the disease as an opportunity for personal growth.

Descriptors: Neoplasms; Child; Child Health; Family; Caregivers.

Objetivou-se investigar as repercussões causadas pelo câncer infantil no cotidiano de familiares de crianças neoplasicamente enfermas. Trata-se de um estudo de campo de abordagem qualitativa e enfoque exploratório-descritivo, tendo a entrevista semiestruturada como instrumento de coleta de informações. 0 estudo foi desenvolvido no Hospital Universitário e no Instituto Paraibano de Combate ao Câncer, ambos localizados em Campina Grande, PB, Brasil, entre os meses de julho e setembro de 2012. O material empírico foi analisado seguindo proposta da análise de conteúdo. Encontram-se como resultados o abalo à qualidade de vida social, sintomas psicológicos e crescimento pessoal. Conclui-se que o câncer infantil trouxe repercussões negativas no cotidiano do familiar cuidador. No entanto, observou-se que é possível construir boas experiências do convívio com a criança enferma e encará-lo como uma oportunidade de crescimento pessoal.

Descritores: Neoplasias; Criança; Saúde da Criança; Família; Cuidadores.

El objetivo fue investigar las repercusiones causadas por el cáncer infantil en la familia de niños neoplásicamente enfermos. Estudio de campo, con enfoque exploratorio, descriptivo, cualitativo, y la entrevista semiestructura da como herramienta para recopilación de informaciones. El estudio fue desarrollado en Hospital Universitario e Instituto contra el Cáncer, ambas en Campina Grande, PB, Brasil, entre julio y septiembre de 2012. El material empírico fue analizado basado en el análisis de contenido. Se encontraron como resultados estremecimiento de la calidad de la vida social, síntomas psicológicos y crecimiento personal. El cáncer infantil trae impacto negativo en cotidiano del cuidador familiar. Sin embargo, se observó que es posible construir buenas experiencias de vivir con un niño enfermo y enfrentarse como oportunidad para el crecimiento personal.

Descriptores: Neoplasias; Niño; Salud del Niño; Familia; Cuidadores.

\footnotetext{
${ }^{1}$ Centro de Ensino Superior e Desenvolvimento. Campina Grande, PB, Brazil.

${ }^{2}$ Faculdades Integradas de Patos. Campina Grande, PB, Brazil. 


\section{Introduction}

Extremely rare, when compared to neoplasm in adults, the child-youth cancer corresponds from $2 \%$ to $3 \%$ of all the malignant tumors, according to the current data of Instituto Nacional do Câncer (Cancer National Institute) $)^{(1)}$. According to the estimates of Ministério da Saúde (Health Department) ${ }^{(2)}$, around 11,530 new cases of cancer in children and adolescents until they are 19 years are expected for the period 2012/2013 in Brazil.

From the epidemiological point of view, the situation of pediatric cancer in Brazil tends to be close to the one experienced in developed countries, and with the control of the parasitarian diseases, the pediatric neoplasia are considered the first cause of death in the age range from 5 to 19 years, in both sexes. Due to the high rate of mortality which reaches $8 \%$, the pediatric tumors are considered a public health problem ${ }^{(1)}$.

The chance of survival for the pediatric tumor is quite high if we consider that the worldwide the rate of cure for this kind of pathology can reach $85 \%$. In Brazil, the percentage of cure of child and youth cancer reaches $70 \%$, which shows that the percentage of cure of Brazilians who developed cancer during childhood is reaching rates which are equivalent to goals of developed countries ${ }^{(3)}$.

However, despite the hope encouraged in the population by the increase of the expectation of cure of child cancer, that is still considered, in the common imaginary, as being and incurable pathology and which presents a close relation with death ${ }^{(4)}$. Under such aspect, the confirmation of the diagnosis of cancer unleashes a destructuring situation not only by those who are attacked by the disease but also by everyone who is around him. The surprise of the diagnosis awakes a moment of stress within the family, which, in turn, leads to modifications in the behavior of the family members ${ }^{(5)}$.

The impact of the disease, especially when it attacks children, promotes a significant change in the family dynamics, jeopardizing the development of the basic tasks of the everyday life. The responsibility of taking care of the sick child, reflects in most of the cases, directly on the life of the mother, leaving her exposed to stressing factors such as: depression, sleep disorders, change in the diet, the social loses, the alteration in the conjugal relation, the alteration with the healthy children and the decrease in the quality of life. But, positive aspects such as personal growth, learning and strengthening can be notorious during this phase $\mathrm{e}^{(6)}$.

It is important to report that, for this study, we consider family as a system or a unit whose members can or not be related or live together, with or without children, and whether they have only one father or not. In this system there is a commitment and a link between its members and the functions of care of the unit which consists in protection, feeding and socialization $^{(7)}$.

The present research is justified by its academic and social relevance of the theme focused, considering that a better comprehension of the effects of living experiences of family members with the pathological process of children with neoplasia will certainly contribute for changes in the assistential practices turned to patients attacked by child cancer. Besides that, we believe that the publicizing of the results of this study helps to sensitize the health professionals, especially the nurse, once she does not only provide assistance to the child, but to the whole family once she is considered an important entity for the maintenance of the quality of life of the child.

This study had as aim the investigation of the repercussions caused by child cancer in the daily lives of family members of children attacked by neoplasia.

\section{Method}

It is a field study of qualitative approach and descriptive-exploratory focus. It was made in two different places: one at the University Hospital and the other at the Instituto Paraibano de Combate ao Câncer 
(IPCCAN) (The Institute Fighting Cancer in Paraíba, Brazil), both located in Campina Grande, Paraíba, Brazil - the city of a county of one of the twelve geo-administrative regions of the state of Paraíba, Brazil $^{(8)}$. Such institutions were chosen as places for the development of the present research because they are currently references in the assistance to children attacked by cancer in this region.

The selection of the subjects of the research was made in a non probabilistic manner and, due to the accessibility and delimitation of those subjects happened through saturation of the answers, as it is proposed by guiding methodological presuppositions of qualitative researches in the area of health ${ }^{(9-10)}$. That is why 11 subjects were selected to participate in the study, having a kinship varying among mother, grandmother, sister and father. The ones who were following the child during the treatment were called to participate.

The following criteria of inclusion were used: being a family member of the diagnosed child by any kind of cancer who has been sick for at least one year, a child who was or has been through some kind of oncological treatment; being older than 18 years; living in the county where the study was made. The subjects who demanded to see the script of the interview in advance were excluded of the research; this criterion was adopted once we believe that the previous knowledge of the question could generate prepared answers, consequently jeopardizing the truthfulness and the spontaneity of the answers. We must highlight that no subject was excluded of the study.

The information was collected from July to September 2012 with the help of a script for a semi structured interview, used as the instrument for the collection of the information. This script contained questions related to child cancer which explored the feelings related to the pathological process of child diagnosis, treatment and care - and to the possible transformation in the family daily life resulting from the pathology.
The interviews were previously scheduled, and there was the care to make them in reserved area the empirical material was recorded with the free and clarified consent of the participant, being later on transcript, a fact that provided more familiarity with its contents.

The analysis of the information proceeded following the theoretical-methodological referential of the analysis of contents ${ }^{(11)}$, thus emerging three categories of analysis: 'The child cancer and the jeopardizing to the quality of the social life of the family caregiver'; 'Psychological damages brought by the child cancer in the family caregiver'; 'The child cancer as an opportunity of personal growth for the family caregiver'. It is highlighted that in order to guarantee the secrecy of the identity of the subjects of the research at the end of each statement we will present the pseudonym "I" (from Interviewee) followed by the number regarding the order of the interviews.

Once the research is involving human beings, the project was submitted to the appreciation of the Committee of Ethics in Research of the Centro de Ensino Superior e Desenvolvimento - CESED (Center of University Teaching and Development) and the Committee of Ethics and Research of the Alcides Carneiro University Hospital, receiving favorable opinion to its performance through CAAE no. 05204612.2.0000.5175.

\section{Results}

Of the 11 subjects of the study, seven were mothers with children definitely diagnosed with Acute Lymphoblastic Leukemia.

The analysis of the empiric material allowed the identification of the repercussions of the child cancer in the everyday life of family members of children attacked by the disease. This section is concerning the presentation of the considerations of the families resulting from the onset of the pathology. The presentation of the categories of analysis pointed 
out from the reports of the subjects of the research is then started.

\section{Category 1 - The child cancer and the jeopardizing to the quality of the social life of the family caregiver}

In this first category, the reports which involved modification in the aspects of the social life of family members were grouped, especially the caregiver (s) of children attacked by any type of neoplasia. The subjects approached aspects related to the conditions of work and to activities of recreation and leisure.

The statement of interviewed no. 6 showed that a disease in any member of the family can destabilize all the members emotionally and even financially: $I$ worked at home, during the winter I would sow, right? When some job came up, I could take it, but now I just take care of him, I can't 'work, I don't have anyone to take care of him, it has to be by myself (I5). Before I discovered her problem, I used to work, I earned 80 reals per week, and now after the disease I just take care of her, running after something, some medicine, always running for what is better for her (I6).

The subjects of the research also referred jeopardizing of the activities of recreation and leisure. The following reports strengthen these statements: $I$ used to like to stroll a lot with them. Today is another thing, I look for more attention, I practically stopped my life to take care of him, it is like going to sleep and waking up knowing that today is there another appointment and he would be hospitalized, this is the way I am living, I've got to think about him now (I8). My life was quite happy, enjoyable, we would walk, we would travel and today he is no longer what he used to be, I have to dedicate everything to him (E9).

Category 2 - Psychological damages brought out by child cancer in the family caregiver

This category represents statements of speeches of the subjects of the research showing damages to mental health developed by the experience with the child who has been attacked by neoplasia.

That's analyze the statements by follows: what is affecting my psychological aspect is that I didn't use to have that kind of life at home. I took care of him, I worked, I studied, I had a stable life in society and not today, today is the whole day inside the house, and this affect my psychological side, I get a little depressive, I put on a lot of weight after I discovered his problem (I11). I get into depression, I got two months living with it, and I even took medicine to prevent suicide. I know that I spent two months and then an aunt of his came to take care of him [child 7], there was no way how, he didn't want anyone, he didn't accept anyone (I7).

\section{Category 3 - The child cancer as an opportunity of personal growth for the family caregiver}

Although the great part of the interviewees stated that the child disease negatively altered their daily lives, we found statements pointing out the positive changes resulting from the relation between care - child - child cancer, with the evidences of personal caregiver's growth. Under this category of analysis, some statement groups confirm such reality.

Let's analyze this report: I was not the mother, I didn't take care of my child. I turned the responsibility to my mother. When he got sick I had to have the responsibility of a mother, so, I started taking care of him more, today I say something like this "I am a mother', I take care of him, I don't want anybody to help with his treatment, it's got to be me (E7).

We have noticed in the statements of I7 how it was, somehow, beneficial for her, the discovery of her child disease, once the interviewee has at last assumed the real role of a mother, a function that she had never lived before, once she always delegated this to her mother (the child's grandmother) the care with her son.

In the following statement the sister of one of the children with cancer reports the fear she had when her brother was diagnosed with such pathology. But, along the experience in the hospital environment, she showed a growth regarding the disease: I was much of a dreamer, I thought that everything that happened with neighbor, would never happen to me, I would work, I would clean the house, everything in a rush, I hardly had time for him. Not today, I've grown, I see that everything can happen, we are in the world and everything 
can happen with us again. My life is only him, I don't go anywhere, just the two of us in one place, I play a little, I bathe him, I fix him up and I put him to sleep, I just live for him (I10).

\section{Discussion}

The results found explore the repercussions caused by child cancer in the daily lives of family members of the children with neoplasia. Itwas possible to perceive that along the interviews, the experiences with the sick child with any type of malign tumor are painful for the family, especially for the family member who assumes the functions of caregiver.

Concerning this, similar results were found in a research made in the countryside of Ceará which had the objective to know the feelings and the experiences of family caregivers facing the diagnosis of cancer in the child ${ }^{(12)}$. The findings in this study under question point to feeling of fears for the life of the child and hopelessness; sadness and fear facing the disease; the sensation of prejudice coming from others. The damages in their family dynamics were also evidenced, especially in the difficulty to conciliate the care, the moving for the treatment, the family relationship and the maintenance of work $^{(12)}$.

The statements of the subjects under this present research pointed to a jeopardizing to the quality of social life of the family caregiver. With the analysis of the empirical material, it was possible to infer that people, before the sickness of the child, would work outside their houses or left to have fun, from the diagnosis presented to experience a different situation having to take care of the child the whole time. This new way of life, many times obliges the family member to leave their jobs and renounce to leisure, to attend to the needs of their sick children. Such change commences to happen from the first symptoms and discovery of the disease, with the search for physicians, for doctors, for hospital beds and medicine, thus consuming all the time that was spent in other activities ${ }^{(13)}$. Under this aspect, a Brazilian study points out that the occurrence of a modification of a routine of a caregiver when he starts to dedicate to this sick child exclusively ${ }^{(14)}$.

With the discovery of the child neoplasia, an experience which had not yet been lived, many family members feel they are obliged to leave behind everything which provides pleasure and it used to be part of their routine - work, walks on the weekend, parties, visits to friends or relatives - because they don't have more time nor availability for such activities $^{(15)}$. We believe that this harm to the quality of social life of the family member of children with cancer, may directly or indirectly have repercussion in psychological damages to the subject.

In dealing with the damage to the mental health of the family caregivers, an aspect which was contemplated in the statements of this research, the scientific literature in the area shows that all the caregivers are vulnerable to a load of stress due to an enormous overload of tasks related to the sick member of the family and to the fact that they have no free time to dedicated themselves to the performance of the daily activities ${ }^{(16)}$.

Among the subjects of this study it was observed that the mother is the family member who submits herself to the most to the changes carried out by the outbreak of child cancer, having to experience new tasks and stop the activities which she used to practice before the disease. Such privations contributed for the emotional disorder, made evident through the depressive reaction or stress which provokes jeopardizing in the care rendered to the child as well as to herself ${ }^{(17)}$.

A study which analyzed the meaning of the chemotherapy treatment for the mothers who experience the situation of a child with cancer ${ }^{(18)}$ showed that the changes imposed to the mother by the treatment of her child generate important internal conflicts, leaving clear signs of physical, mental and emotional weariness. In the statements of the interviewed mothers, the authors observed ambiguity related to the meanings of chemotherapy, sometimes it looked to them as if the treatment would be able to 
give the life of the child back, and sometimes showing itself as a treatment permeated by feelings of fear facing the uncertainties of the course of the disease, including its reappearance and the fear of death ${ }^{(18)}$.

The strength and the perseverance in coping with the child cancer were evidenced in a Brazilian study on the experience of families in situation of living with the cancer. It was revealed that the search for overcoming the disease, the change of habits, the compliance with the obligations and the religious attachment as strategies to bravely face the situation of the disease thus improving the confrontation of the pathology and bringing positive answers for the family caregiver made it more feasible ${ }^{(19)}$.

The findings placed in category 3 "The child cancer as an opportunity of personal growth for the family caregiver' confirm the positioning of a Brazilian author ${ }^{(20)}$, when he states that even if the suffering brings changes in the family dynamics there is the possibility of mutual learning and comprehension among the members of the family nucleus. Regarding this aspect we reiterate that although the cancer is still linked to extremely negative feelings and sensations - pain, suffering, mutilation and death it is still possible to live positive experiences, which according to a research made in Brazil(12), it involves both maturity and the personal growth of the family caregiver as well as the strengthening of family bonds.

\section{Final Considerations}

This study makes possible to unveil part of the everyday life of the family members who live with children attacked by cancer, emphasizing modifications experienced by the family caregivers in their day-by-day experiences. Some of them had to renounce their professional obligation, which in a way provoked stress and depression. Others transformed their routine of leisure in order to provide assistance to the especial needs of the sick child, which are considered as a negative change in the everyday life of the caregiver.
Taking care of a sick child can bring many damages to the quality of life, both of the caregiver as well as of the family as a whole, but this study allows us to see something positive in this context. Caregivers reported experiences of personal growth during the process of living with the child cancer, who acquired maturity and a new way to face the difficulties developing a bigger responsibility and seriousness facing the facts. The optimization of time was also evident once in some reports the lack of time that the family member had to take care of the child before the discovery of the pathology was evident; such reality was modified after the diagnosis of the disease.

The findings of this study allow us to observe that the family caregivers of children with cancer struggle for the health of his beloved one, going through stressful moments. It was evident that there is the need of attention that these family members have, especially if we consider the sensation of insecurity, the change in the routine of life, the feeling of sadness and even depressive processes.

Facing these results we consider the need of the health professionals essential to know the reality both of the children with neoplasia as well as the family caregivers, considering the family nucleus as the focus of care for the health team. It is fundamental to have a more careful and attentive look so that the signs of difficulty/suffering in the family nucleus can be early identified and help them to face the process of the disease of the child.

The findings in this research contribute for the sensitization of the health professionals on the need of care that the family members of children with cancer present. We reinforce the importance of other researches on the experience of the family members regarding the children attacked by neoplasias in order to enhance and unveil the everyday experiences of the family caregiver. We believe that the advancement of the researches on the focused theme has the potential to improve the quality of assistance rendered to the child with cancer and to the relative that lives such experience. 


\section{Collaborations}

Medeiros EGMS participated in the conception of the research, developed the analysis collection and data discussion stages and in the writing of the final report. Leite RFB contributed for the orientation and development of the research. Ramos DKR worked in the writing and structuring of the article and in the approval of the final version. Almeida LAL contributed for the writing and regulation of the article stages.

\section{References}

1. Instituto Nacional do Câncer. Câncer na criança e no adolescente no Brasil: dados dos registros de base populacional e de mortalidade. Rio de Janeiro: INCA; 2008.

2. Instituto Nacional de Câncer. Particularidades do câncer infantil. Brasília: Ministério da Saúde; 2012.

3. Instituto Nacional do Câncer. Estimativa 2008: incidência de câncer no Brasil. Rio de Janeiro: INCA; 2007.

4. Guerrero GP, Zago MMF, Sawada NO, Pinto MH. Relationship between spirituality and cancer: patient's perspective. Rev Bras Enferm. 2011; 64(1):53-9.

5. Costa P, Leite RCBO. Estratégias de enfrentamento utilizadas pelos pacientes oncológicos submetidos a cirurgias mutiladoras. Rev Bras Cancerol. 2009; 55(4):355-64.

6. Beltrão MRLR, Vasconcelos MGL, Araújo EC. A criança com câncer e a família: contexto, descoberta e ação. In: Malagutti, W. Oncologia pediátrica: uma abordagem multiprofissional. São Paulo: Martinari; 2011. p.21-34.

7. Instituto para o Desenvolvimento da Saúde. Universidade de São Paulo. Ministério da Saúde. Manual de enfermagem. Brasília: Ministério da Saúde; 2001 (Série A. Normas e Manuais Técnicos, no 135).

8. Brandão ICA, Martiniano CS, Monteiro AI, Marcolino EC, Brasil SKD, Sampaio J. Análise da organização da rede de saúde da Paraíba a partir do modelo de regionalização. Rev Bras Ciênc Saúde. 2012; 16(3):347-52.

9. Minayo MCS. O desafio do conhecimento: pesquisa qualitativa em saúde. São Paulo/Rio de Janeiro: Hucitec/Abrasco; 2008.

10. Turato ER. Tratado de metodologia da pesquisa clinico-qualitativa: construção teóricoepistematológica discussão comparada e aplicação nas áreas de saúde e humanas. Rio de Janeiro: Vozes; 2003.

11. Bardin L. Análise de conteúdo. Lisboa: Edições70; 2009.

12. Firmino CDB, Sousa MNA. Sentimentos e vivências de familiares em frente ao diagnóstico de câncer na criança. Rev Bras Pesq Saúde. 2013; 15(2):612.

13. Quirino DD, Collet N. Cancer among infants: adjustments in family life. Texto Contexto Enferm. 2012; 21(2):295-303.

14. Silva TCO, Barros VF, Hora BC. Experiência de ser um cuidador familiar no câncer infantil. Rev Rene. 2011; 12(3):526-31.

15. Santos LMP, Gonçalves LLC. Crianças com câncer: desvelando o significado do adoecimento atribuído por suas mães. Rev Enferm UERJ. 2008; 16(2):224-9.

16. Ignacio MG, Storti DC, Bennute GRG, Lucia MCS. Aspectos da sobrecarga em cuidadores de pacientes terminais por câncer: revisão de literatura. Psicol Hosp. 2011: 9(1):24-46.

17. Nascimento CAD, Monteiro EMLM, Vinhaes AB, Cavalcanti LL, Ramos MB. O câncer infantil (leucemia): significações de algumas vivências maternas. Rev Rene. 2009; 10(2):149-57.

18. Oliveira RR, Santos LF, Marinho KC, Cordeiro JABL, Salge AKM, Siqueira KM. Ser mãe de um filho com câncer em tratamento quimioterápico: uma análise fenomenológica. Ciênc Cuid Saúde. 2010; $9(2): 374-82$.

19. Ferreira NML, Dupas G, Costa DB, Sanchez KDL. Câncer e família: compreendendo os significados simbólicos. Ciênc Cuid Saúde. 2010; 9(2):269-77.

20. Castro EHB. Mães de crianças com câncer: repercussões familiares, pessoais e sociais. Rev Psicol Saúde. 2010; 2(2):56-64. 